\title{
Brand Architecure in Higher Education: could it work in new and developing universities?
}

\section{Purpose}

Increasingly Higher Education Institutions (HEIs) are facing uncertainties and pressures with a strong emphasis to differentiate from competitors with a clear offering to multiple stakeholders (Amber et al., 2016; Anctil, 2008; Chapleo, 2010; Hemsley-Brown and Oplatka, 2006). Universities in particular are viewed as 'businesses' operating in a competitive global marketplace where differentiation plays a key role in attracting students and funding (Walton, 2005; Bunzel, 2007). One subject area that seems to address some of the uncertainties and pressures is the topic of corporate branding. Corporate branding can alleviate universities from a complex set of multi-faceted features (Hemsley-Brown and Goonawardana, 2007) which include among others, accreditation, tuition fees, positions in league tables and status in the global marketplace, and reinforce an institution's unique selling point to multiple stakeholders, such as students, academics and funders (Whisman, 2009; Chapleo, 2010). Thus, a strong corporate brand can support, for example, charging higher tuition fees, recruiting leading academics and attracting students from underrepresented groups (Chapleo, 2010; Croxford and Raffe, 2015).

Despite a move towards 'marketisation', it is unclear whether corporate branding has allowed universities to develop authentic, convincing brand identities, which would help to alleviate these pressures as $\mathrm{HE}$, unlike the private sector, has typically less resources to implement branding strategies and has a tendency to be internally focused, unsure what is important for their brand and stakeholders (Jevons, 2006). The limited studies in this area call for more research and understanding into the application of corporate branding in the context of higher education (Anctil, 2008; Chapleo, 2010; Hemsley-Brown and Oplatka, 2006). Dibb and Simkin (1993, p.26) discuss the branding variance of intangibility in different services placing "education" at the extreme end of the continuum questioning: "what is the product, the institution, the course; the experience or the qualification?"' It could be these different specialisms may be the very source of differentiation that can ensure the success of a HE corporate brand. Although "higher education and branding go back a long way" (Temple, 2006: p.15) those branding studies that have been conducted in universities have had limited application in specialised areas (Hankinson, 2004; Chapleo, 2011) such as the sciences or teacher education, as opposed to a business school where most marketing research is generally undertaken. Balmer and Liao (2007, p. 368) point to other 'institutional settings' such as the Department of Music, at the University of York, which warrant a study with students into their identification with a university's corporate brand. This highlights the complexity and challenges of managing multiple sub-brands within a corporate brand (Spry, 2014; Chapleo, 2015) and presents a unique opportunity for the research proposed which will consider relationships between a university corporate brand and sub-brand. As corporate branding can be described as the process of framing the organisation's identity, which is derived from its culture, values, strategy and tangible cues (Balmer, 2001) it is brand identity that is the "unit of analysis" (Uggla, 2006, p.78) and the focus of this study.

Specifically, corporate brand identity relates to "what the organisation is and what it seeks to be" (Abratt and Kleyn, 2012, p.1051). Similarly Steiner et al (2013, p. 411) maintain that a university's identity is “who we are”. Since Albert and Whetten's (1995) study on organisational identity and the authors' claim that it is an evolving, collective phenomenon, 
there has been an increasing interest in institutional identity. Indeed, the link between corporate brand identity and shared values amongst stakeholders has been extensively documented (Harris and de Chernatony, 2001; Balmer and Gray, 2003, Kay, 2006; Chapleo, 2010). These "bundle of values..." (Balmer and Gray, 2003, p. 981) give the organisation its uniqueness and "....a sense of individuality" (Harris and de Chernatony, 2001, p. 442). Balmer (2001) maintains that the values of an organisation's identity as can be both tangible and intangible. However, with increasing competition in the marketplace and the rapid progress of modern technology organisations are looking to differentiate the emotional, rather than functional characteristics of their brand (Harris and de Chernatony, 2001). Gutman and Miaoulis (2003, p.106) describe these emotional values as those "that underlie important goals of students ...." which "deal with the end states of our existence or the ultimate goals that people wish to achieve in their lives" (Durvasula et al., 2011, p. 33). Thus the corporate brand becomes "the interface between the organisation's stakeholders and its identity" (Abratt and Kleyn, 2012, p. 1053) and a transition occurs from university identity to image (Steiner et al., 2013). It is therefore an organisation's 'values' that should correspond with the emotional needs of both employees and external stakeholders (Chapleo, 2010; Harris and de Chernatony, 2001). However, Steiner et al (2013) maintain that university faculties may not see themselves as part of the university's overall identity which Brookes (2003:139) argues is due to marketing concepts being "theoretically uncomfortable" for most academics or even "insulting" (Waeraas and Solbakk, 2008).

Traditionally, centralised corporate branding has played a less visible role in HE which has allowed different departments to develop strong brand identities of their own, referred to as the "house of brand approach" (Hemsley-Brown and Gonnawardana, 2007, p. 946). This approach is one of four key branding strategies which Aaker and Joachimsthaler (2000) place on a spectrum and relate to the discipline of brand architecture. For example, the house of brands approach puts distance between the corporate brand and the businesses and products such as the Virgin Group. The second approach is that of the branded house where a single Masterbrand unites the company and its businesses and products, such as the Virgin Group. Hemsley-Brown and Gonnawardana (2007, p.945) refer to this approach as "corporatization" in universities and is when branding practices change and departments are encouraged to align their identity with that of the university; hence they lose their individual branding. This particularly affects departments operating in niche markets and presents a difficult challenge for universities where understanding and expressing a single identity "may be too complex and fragmented" (Waeraas and Solbakk, 2009, p. 459) as multiple identities and values held by staff may provide uniqueness to the university. Jevons (2006) cites the University of Cambridge in the UK where the identity of their colleges is much more distinct than the entire University. The endorsed brand strategy is when a company's businesses and products are endorsed with the corporate brand (Aaker and Joachimsthaler, 2000) and a common identity such as Courtyard by Marriott. Sub-brands are also part of the brand architecture arena and similarly to endorsed brands can stretch across products and markets with an offering that is different and new (Uggla, 2006). Hemsley-Brown and Gonnawardana (2007) refer to university faculties/schools/departments as sub-brands where the university simply provides brand endorsement to the sub-brands. However, Devlin (2003) maintains there are subtle differences between sub-brands and endorsed brands; in the latter case the Masterbrand plays a far less dominant role than that of the former which allows the Masterbrand to compete in markets than would otherwise be the case (Hsu et al, 2014). If the Masterbrand is more distant as in the endorsed approach, it cushions against any possible contamination and risk (Hsu et al, 2014). Devlin (2003) cites the key reason for putting distance between the corporate brand and businesses and products as being to maintain relationships and indicate 
distinctive competencies to different target markets. For example, and in the context of HE, while a University has key stakeholders, such as the Government, the general public and media it would seem worthy of consideration that the corporate brand might shape different images for these stakeholders while allowing different specialisms, particularly those with strong but different external influences, to nurture relationships with specific target markets (Muzellec and Lambkin, 2008). Although clear brand architecture models have been developed over time in the literature there appears to be a conflict of views and a lack of context-specific approaches. For example Chapleo (2015) found in his research that university departments often displayed qualities of sub-brands for specific target markets. However, there is no literature that has applied these different brand architecture approaches to the context of a university and more specifically a particular area of specialism. Indeed Chapleo (2015, p.159), who maintains that brand architecture is an approach "with which universities struggle", calls for more research into its applicability.

Responding to the identified gaps in the body of knowledge this research, which provides a unique insight into an under-researched area, seeks to examine a university's identity, related values and considers the development of an operational framework. The framework will investigate the complex nature of corporate brands in the context of HE in order to identify a coherent and effective brand architecture (Aaker and Joachimsthaler, 2000) which signals a differentiated offering? Although Spry (2014) responded to these gaps by qualitatively exploring perceptions of staff and students in a UK university and found significant relationships between the corporate brand and sub brand there is a need for a quantitative study that examines the suggested relationships further. The context is a university in the Republic of Ireland (RoI) focusing on a College of Nursing. The findings will offer internal university management advice on how best to investigate and potentially manage multiple sub-brands and ensure consistencies and coherencies with the corporate brand. Therefore the following objectives for this study have been developed:

- To explore perceptions of corporate brand identity-image by students in both the context of a university and that of a university department

- To examine the role that corporate brand identity plays in shaping perceptions of emotional and functional values

- To conceptualise a framework that university practitioners can assimilate in order to develop appropriate brand architectures.

\section{Research Design}

\section{Method}

A survey was conducted in September 2016 at a University in the Republic of Ireland and more specifically a College of Nursing. A total of 165 questionnaires were collected from final year undergraduate students and Masters students, studying at the College of Nursing. The majority of respondents were female (84\%) and aged between $22-30(76 \%)$. One respondent was dropped from the study after data cleaning and as a result, data from 164 respondents was used to test the hypotheses. Hair et al. (2010) maintain that a minimum sample size for a model with five or fewer constructs is 100 . 


\section{Conceptual Framework and Hypotheses}

In keeping with objectives developed in the previous section, the following conceptual model has been developed. All validated items of the variables in the conceptual framework were heavily influenced by the work of Lages and Fernandes (2005).

\section{Figure 1 Conceptual Framework}

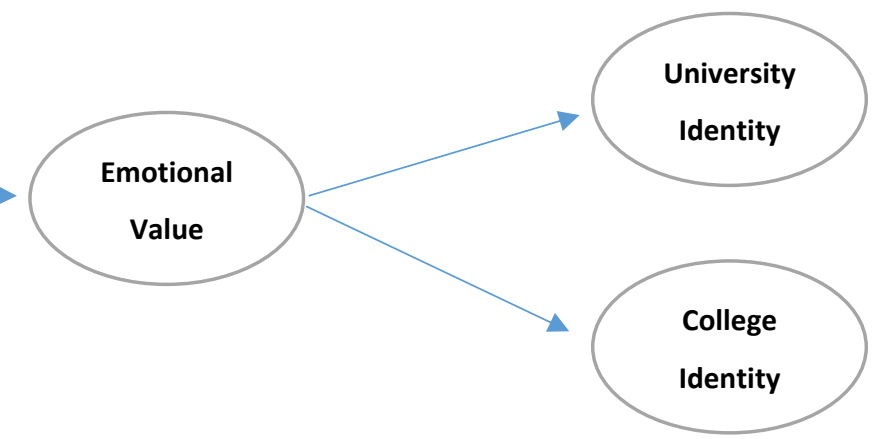

Although the analysis has not yet been completed this study will use Amos 23.0 to test the model and Confirmatory Factor Analysis (CFA) and Structural Equation Modelling (SEM) will be employed to assess the model fit and test the hypotheses respectively. Further, this study follows the bootstrapping method developed by Preacher and Hayes (2008) to test the mediating role of perceived Emotional Values.

So as to gain a more detailed understanding of the relationships highlighted in figure 1, including the strength of the causal relationships and differences, the follow three hypotheses have been developed:

\section{H1: Perceived emotional values will positively influence a university's identity}

\section{H2: Perceived Emotional values will positively influence a college's identity}

\section{H3: Functional values will positively influence perceived emotional values}

In addition, two further hypotheses have been developed to test if perceived emotional values act as a mediator between identity and perceived functional values. This will measure the importance of perceived emotional values as a key element of branding strategies to be considered by university management:

H4: Perceived emotional values mediate a positive relationship between perceived functional values and university identity

H5: Perceived emotional values mediate a positive relationship between perceived functional values and a college's identity 


\section{Discussion}

This research will offer insight into students' attitudes and opinions of both the University and that of the College of Nursing in terms of values. Specifically, the questions posed to students will provide an understanding on how they view the University's identity compared to that of the College of Nursing. This will also help us to understand how successful the university has been in implementing its corporate branding initiatives and whether or not the corporate brand values align with that of the School of Nursing. In other words, do College staff perform in a way that the University (identity) and the students (image) expect? More specifically, do the values of the University, and that of the College of Nursing align with those of the students or are they viewed as separate entities with different perceptions as a result? Therefore is there a gap between the communicated corporate HEI brand identity and understood image? Further, can any relationship be identified between the corporate brand identity and emotional and functional values? Specifically, we are interested to see if emotional values mediate a positive relationship between corporate brand identity and functional values. In addition, does this suggest a sub-culture (sub-brand) within the corporate brand? If this is the case is it possible that different specialisms may provide the very source of differentiation being sought by universities across the globe?

It is proposed to develop and test a framework that can be applied to HE and other organisations where there may be different departments with different sub-cultures operating in different environments. HE institutions will be able to use the proposed framework as a mechanism to understand the interplay, relationships and identity-image of the corporate brand and subbrands. This in turn will enable HEI's to respond to findings and develop-refine HE branding strategies for future development to shape, direction, values, vision etc. and highlight the most appropriate brand architecture to develop. The framework will also offer corporate brands within and beyond the HE context on how to evaluate their corporate brand and ascertain whether a house of brands or branded house approach is suitable for long term development.

\section{Conclusion}

It is proposed that research will add to the limited studies in HE and corporate branding both in terms of context and furthering the concept of corporate brand identity and, in particular brand architecture where HE literature is virtually non-existent. This study will also contribute to educational branding theory through demonstrating an understanding of those values that are most important to students therefore advancing understanding the development of global 'educational brands'. Future comparative studies could be conducted to assess the transfer potential of the proposed framework to national and international settings and make adaptations if required. This research forms part of a larger study and qualitative data has been collected from employees in the College of Nursing which would also support these findings. If time allows findings from this would also be presented at the conference. 


\section{References}

Aaker, D. A., and E., Joachimsthaler. (2000). The brand relationship spectrum: the key to the brand architecture challenge. California Management Review, 42, 4, 8-23.

Abratt, R., and Kleyn, N. (2012). Corporate identity, corporate branding and corporate reputations: reconciliation and integration. European Journal of Marketing, 46(7/8), 1048-1063.

Albert, S., and Whetton, D. A. (1985). Organisational identity. Research in Organisational Behaviour, 7, 263-295.

Anctil, E.J. (2008). Marketing and advertising the intangible. ASHE Higher Education Report, 34(2), $31-47$.

Balmer, J. M. T. (2001). Corporate identity, corporate branding and corporate marketing: Seeing through the fog. European Journal of Marketing, 35(3/4), 248-291.

almer, J. M. T., and Gray. E. R. (2003). Corporate brands: what are they? What of them? European Journal of Marketing, 37(7/8), 203-233.

Balmer, J. M. T., Liao M-N (2007). Student corporate brand identification: an exploratory case study. Corporate Communicatons: An International Journal, 12, 4, 356-375.

Brookes, M. (2003). Higher Education: Marketing in a quasi-commercial service industry. Journal of Nonprofit and Voluntary Sector Marketing, 8, 2, 134-142.

Bunzel, D. L. (2007). Universities sell their brands. Journal of Product \& Brand Management, 16(2), 152-153.

Chapleo, C. (2010). What defines "successful" university brands? International Journal of Public Sector Management, 23(2), 169-183.

Chapleo, C. (2011). Exploring rationales for branding a university: should we be seeking to measure branding in UK universities. Journal of Brand Management, 18(6): 411-422.

Chapleo, C. (2015). Brand in higher education: challenges and potential strategies. International Studies of Management \& Organisation, 45(2): 150-163.

Croxford, L., and Raffe, D. (2015). The iron law of hierarchy? Institutional differentiation in UK higher education. Studies in Higher Education, 40(9), 1625-1640.

Dibb, S., and Simkin, L. (1993). The strength of branding positioning in services. International Journal of Service Industry Management, 4, 1, 25-35.

Durvasula, S., Lysonski S, Madhavi, A. D. (2011). Beyond service attributes: do personal values matter: Journal of Services Marketing, 25/1, 33-46.

Gutman, J., and Miaoulis, G. (2003). Communicating a quality position in service delivery: an application in higher education. Managing Service Quality, 13, 2, 105-111.

Hair, J. F., Black, W. C., Rabin, B. J., \& Anderson, R. E. (2010). Multivariate data analysis: A global perspective. New Jersey: Pearson Prentice Hall.

Hankinson, P. (2004). The internal brand in leading UK charities. Journal of Product \& Brand Management, 13, 2, 94-93. 
Harris, F., and de Chernatony, L. (2001). Corporate branding and corporate brand performance. European Marketing Journal, 35(3/4), 441-456.

Hemsley-Brown, J., and Oplatka, I. (2006). Universities in a competitive global marketplace: a systematic review of the literature on higher education marketing. International Journal of Public Sector Management, 19(4), 316-338.

Hsu, L., Fournier, S., Srinivasa, Shuba. (2015). Brand architecture strategy and firm value: how leveraging, separating, and distancing the corporate brand affects risk and returns. Journal of the Academy of Marketing Science, DOI 10.1007/s11747-014-0422-5

Lages, F, L., and Fernandes, J. C. (2005). The SERPVAL scale: a multi-item instrument for measuring service personal values. Journal of Business Research, 58, 1562-1572.

Hemsley-Brown, J., and Goonawardana, S. (2007). Brand harmonization in the international higher education market. Journal of Business Research, 60, 942-948.

Jevons, C. (2006). Universities: a prime example of branding going wrong. Journal of Product \& Brand Management, 15(7), 466-467.

Kay, M. J. (2006). Strong brands and corporate brands. European Journal of Marketing, 40(7/8), $742-$ 760.

Muzellec, L., and Lambkin, M. (2008). Corporate branding and the implication for brand architecture management: the case of Guinness (Diageo) Ireland. Journal of Strategic Marketing, 16, 4, 283-299.

Preacher, K. J., Rucker, D. D., \& Hayes, A. F. (2007). Assessing moderated mediation hypotheses: Theory, methods, and prescriptions. Multivariate Behavioral Research, 42, 185-227.

Spry, L. M. (2014). A study of corporate branding in a Higher Education Institution in the 21st Century. Nottingham Trent University.

Steiner, L., Sundström, A. C., and Sammalisto, K. (2012). An analytical model for university identity and reputation strategy work. Higher Education, 65, 401-415.

Temple, P. (2006). Branding higher education: illusion or reality? Perspectives: policy and practice in higher education, 10(1), 15-19.

Uggla, H. (2006). The corporate brand association base: a conceptual model for the creation of inclusive brand architecture. European Journal of Marketing, 40, 7/8, 785-802.

Waerass, A., and Solbakk, N. (2009). Defining the essence of a university: Lessons from higher education branding. Higher Education, 57(4), 449-462.

Walton, J. (2005). Would the real corporate university please stand up? Journal of European Industrial Training, 29(1), 7-20.

Whisman, R. (2009). Internal branding: a university's most valuable intangible asset. Journal of Product \& Brand Management, 18/5, 367-370. 